Mancini, G., Carbonara, A. O., and Heremans, J. F. (1965). Immunochemistry, 2, 235.

Mercola, K. E., and Hagadorn, J. E. (1973). Experimental and Molecular Pathology, 19, 230.

Murray, M. J., and Thal, A. P. (1960). Annals of Internal Medicine, 53, 548.

Pepys, J. (1971). In New Concepts in Allergy and Immunology, ed. U. Serafini, et al., p. 136. Amsterdam, Excerpta Medica Foundation.
Soothill,. J. F. (1967). Clinical and Experimental Immunology, 2, 83. Soothill, J. F., and Hendrickse, R. G. (1967). Lancet, 2, 929. Stein, A. A et al. (1964) Fournal of Pediatrics, 65, 495.

Wallwork, J. C., et al. (1974). Clinical and Experimental Immunology, 18, 303.

Warren, C. P. W., and Tse, K. S. (1974). American Review of Respiratory Diseases, 109, 672.

\title{
Lymphocyte Reactivity in Pregnant Women and Newborn Infants
}

\author{
V. Y. H. YU, C. A. WALLER, I. C. M. MACLENNAN, J. D. BAUM
}

British Medical fournal, 1975, 1, 428-432

\section{Summary}

The mitotic response to phytohaemagglutinin (PHA) was determined in lymphocytes of mothers and their newborn infants obtained at delivery and seven days later by measuring the rate of ${ }^{125}$ I-idoxuridine uptake into DNA in lymphocytes cultured in their own plasma and after washing and resuspension in fetal bovine serum. There was no difference in the unstimulated counts of maternal lymphocytes taken at delivery, whether unwashed or washed, compared with those from nonpregnant controls. With PHA stimulation the mitotic response of the maternal lymphocytes cultured in their own plasma was reduced compared with that of the control lymphocytes but washed maternal cells showed a similar response to the controls. These findings suggest that the reduced lymphocyte mitotic response to PHA in pregnancy is due to a plasma inhibitory factor. This inhibition was not evident in maternal blood taken seven days after delivery.

DNA synthesis in unstimulated cultures from newborn infants at birth and seven days after birth was greater than that in adult control cultures. With PHA stimulation the mitotic response of cord-blood lymphocytes cultured in their own plasma paralleled that of control lymphocytes but washed newborn cells showed a greater response. Thus plasma suppression similar to that observed in the mother seems also to affect infants at birth. This inhibition was not demonstrable in blood taken from infants of 7 days.

\section{Introduction}

In most pregnant women the mitotic response of their lymphocytes to phytohaemagglutinin (PHA) is reduced (Purtilo et al., 1972), but the process by which this response, which seems to be predominantly the property of $\mathrm{T}$ cells, is reduced is uncertain (Finn et al., 1972). Divergent results have been obtained regarding the suppressive effect of serum from pregnant women

University Department of Paediatrics, John Radcliffe Hospital, Oxford OX3 9DU

V. Y. H. YU M.B. M.R.C.P. Research Fellow

J. D. BAUM M.D. M.R.C.P. First Assistant

Nuffield Department of Clinical Medicine, Radclifie Infirmary, Oxford OX2 6HE

C. A. WALLER B.A. Technician

I. C. M. MACLENNAN PH.D. M.R.C.PATH. Head of Clinical Immunology Research Unit on the PHA response of lymphocytes from normal healthy donors (Purtilo et al., 1972; Walker et al., 1972). A recent study indicated the presence of a serum inhibitor in pregnancy (St Hill et al., 1973) but its nature and origin is unknown. There are several conflicting reports on the response of cord-blood lymphocytes to PHA (Lindahl-Kiessling and Böök, 1964; Leikin et al., 1968; Meuwissen et al., 1968; Jones, 1969; Campbell et al., 1975).

We have studied the mitotic responses to PHA of the lymphocytes of mothers and their newborn infants, obtained at delivery and seven days later. To investigate the presence of an inhibitory plasma factor we also compared the PHA responses of lymphocytes cultured in the presence of autologous plasma with those after washing the cells and resuspending them in fetal bovine serum.

\section{Patients and Methods}

Collection of Blood Samples.-Blood samples were obtained by venepuncture from 24 mothers at delivery, and 24 samples of cord blood were collected from their newborn infants at the same time. In each case $5 \mathrm{ml}$ of blood was anticoagulated with preservative-free heparin and an EDTA sample was taken for a white cell and differential count. All samples were cultured within 24 hours of collection and in most cases within 12 hours. With each batch of samples tested control samples of venous blood, taken from age-matched healthy non-pregnant women, were treated in the same manner. Blood samples were also obtained from 13 of the mothers and their infants seven days after delivery and were similarly treated.

Preparation of Cultures.-A whole-blood microtechnique similar to that described by Maini et al. (1973) was used in setting up the cultures. Tubes were set up in triplicate each containing $1 \mathrm{ml}$ of minimal essential medium (M.E.M.) supplemented with glutamine, non-essential amino-acids, and antibiotics to which $0.1 \mathrm{ml}$ of the blood sample was added. PHA (Wellcome, dried reagent, lot K6888) was added to a concentration of $1 / 100$. Triplicate tubes were also set up without added PHA. Preparations of washed cells were made by first diluting $2 \mathrm{ml}$ of the blood sample with $20 \mathrm{ml}$ of M.E.M. under which about $4 \mathrm{ml}$ of heat-inactivated fetal bovine serum (Biocult, batch 000239) was lavered. The cells were then centrifuged through the layer of fetal bovine serum and the autologous plasma removed by sucking off the supernatant until $2 \mathrm{ml}$ remained. After resuspension of the cells $0.1 \mathrm{ml}$ was added to each culture tube and similarly treated as the unwashed cell cultures.

Assessment of Lymphocyte Response to PHA.-The cultures were incubated for 72 hours at $37^{\circ} \mathrm{C}$. DNA sythesis was estimated by incorporation of 125I-idoxuridine (Craig et al., 1969). A stock solution of this reagent (Radiochemical Centre, Amersham) was made up with added cold deoxyuridine to a concentration $10 \mathrm{mg} / 1$ and an activity of $20 \mathrm{mCi} / 1$. From this solution $0.05 \mathrm{ml}(1 \mu \mathrm{Ci})$ was added to each tube three hours before the end of culture after taking off $0.5 \mathrm{ml}$ of culture medium. At the end of the culture the cells were spun down and the supernatant containing the excess isotope decanted off. Red cells were lysed by washing 
with $2 \%$ acetic acid in normal saline, and the res:due was washed and spun down sequentially in normal saline, $10 \%$ trichloroacetic acid (twice), and methanol. This extreme washing was necessary to reduce to low levels the isotope activity not specifically bound to the material precipitated by trichloroacetic acid. The radioactivity of the residue was counted in a Wallac Decem automatic gamma-counter and the results calculated as counts per minute (c.p.m.) after correcting for decay of isotope and variations in counter efficiency.

\section{Results}

The average counts per minute of the triplicate cultures were plotted and expressed logarithmically. The mitotic response to PHA was derived by subtracting the count per minute in the unstimulated culture from that of the PHA-stimulated culture of the same sample. Statistical analyses were by Student's $t$ test for data between subject groups and the paired $t$ test for unwashed and washed cell cultures in the same group. The results of all lymphocyte cultures are summarized in tables I and II.

There was no significant difference in unstimulated counts of non-pregnant adult controls, mothers at delivery, and mothers seven days after delivery, and similar unstimulated counts were obtained for both unwashed and washed cell cultures. The mitotic response to PHA of maternal lymphocytes taken at delivery was, however, reduced compared with that of the lymphocytes of non-pregnant controls when the cells were cultured in the presence of their own plasma $(P<0.01)$. Washed cells, in contrast, had a similar mitotic response to that of non-pregnant control cells and the responses of the unwashed and washed cell cultures were significantly different ( $P<0.001$; fig. 1). Lymphocytes from mothers seven days after delivery had a mitotic response similar to the control response and there was no difference between unwashed and washed cell cultures.

DNA synthesis in unstimulated cultures of cells from newborn infants at birth and at 7 days of age was significantly greater than that in the cells of adult controls $(P<0.001)$. Similar unstimulated counts were obtained for both unwashed and washed cell cultures. Mitotic response to PHA of cordblood lymphocytes paralleled that of adult control lymphocytes when the cells were cultured in the presence of their own plasma. Washed cells, however, had a greater mitotic response than adult control cells and the responses of the unwashed and washed cell cultures were significantly different $(P<0.001$; fig. 2). Lymphocytes from 7-day-old infants had a greater
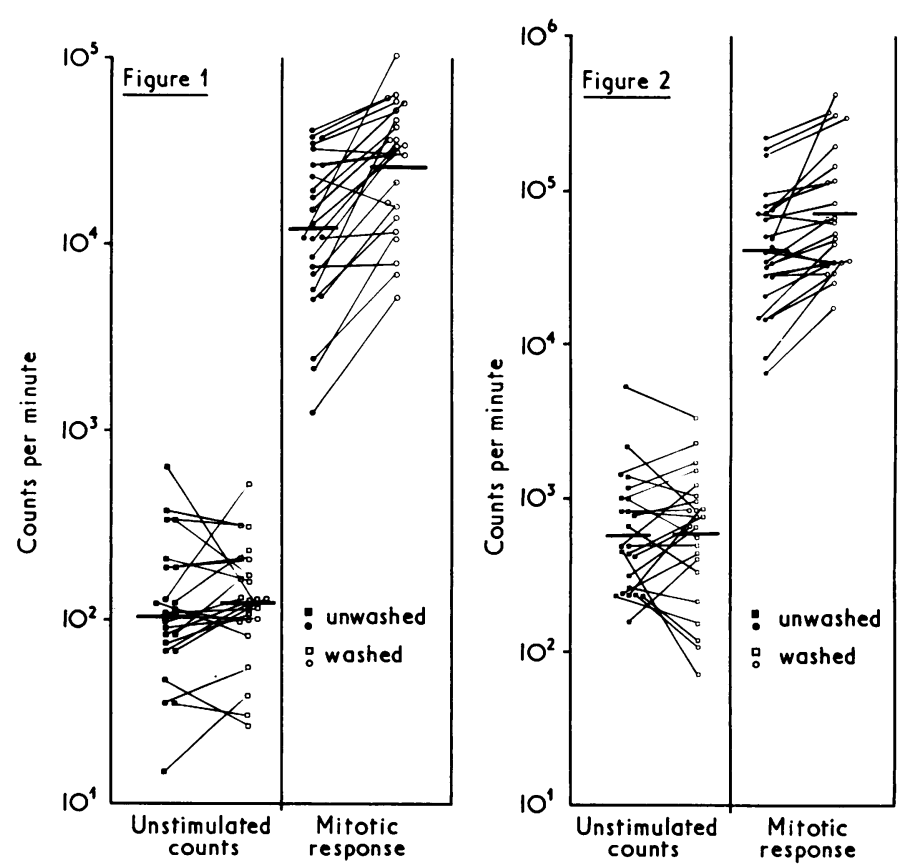

FIG. 1-Mitotic response to PHA of maternal lymphocytes obtained at time of de ivery from 24 women. Horizontal lines represent means. FIG. 2Mitotic response to PHA of newborn lymphocytes obtained at time of delivery from 24 infants. Horizontal lines represent means.

mitotic response than adult control cells $(P<0.005)$ and there was no difference between unwashed and washed cell cultures.

\section{Discussion}

Lymphocyte response to PHA is an expression of a facet of T-cell immunity (Bloom, 1971) though some B cells may respond in some circumstances (Phillips and Weisrose, 1974). The maternal lymphocyte response to PHA may be depressed during pregnancy (Purtilo et al., 1972; Finn et al., 1972), and our results indicate that this persists up to the time of delivery. Other evidence which indicates lowered maternal immunity includes impaired in-vitro lymphocyte response to purified protein derivative (Smith et al., 1972) and prolonged homo-

TABLE I-Lymphocyte Response of Phytohaemagglutinin in Mothers and Children. Results are expressed as Logarithmic Means \pm S.D. Arithmetic Means are shown in Parenthesis

\begin{tabular}{|c|c|c|c|c|c|c|c|c|c|c|c|c|c|c|c|c|}
\hline \multirow{2}{*}{\multicolumn{2}{|c|}{ Culture }} & \multicolumn{3}{|c|}{$\begin{array}{l}\text { Non-pregnant Controls } \\
\quad(\mathrm{n}=16)\end{array}$} & \multicolumn{3}{|c|}{$\begin{array}{l}\text { Mothers at Delivery } \\
(\mathrm{n}=24)\end{array}$} & \multicolumn{3}{|c|}{$\begin{array}{c}\text { Mothers } 7 \text { Days after } \\
\text { Delivery }(\mathrm{n}=13)\end{array}$} & \multicolumn{3}{|c|}{$\begin{array}{l}\text { Infants at Birth } \\
(\mathbf{n}=24)\end{array}$} & \multicolumn{3}{|c|}{$\begin{array}{l}\text { Infants } 7 \text { Days after } \\
\text { Birth }(\mathrm{n}=13)\end{array}$} \\
\hline & & $\begin{array}{c}\text { Un- } \\
\text { washed } \\
\text { Cells }\end{array}$ & $\begin{array}{l}\text { Washed } \\
\text { Cells }\end{array}$ & $\begin{array}{c}\mathbf{P} \\
\text { Values }\end{array}$ & $\begin{array}{c}\text { Un- } \\
\text { washed } \\
\text { Cells }\end{array}$ & $\begin{array}{l}\text { Washed } \\
\text { Cells }\end{array}$ & $\begin{array}{c}\mathbf{P} \\
\text { Values }\end{array}$ & $\begin{array}{c}\text { Un- } \\
\text { washed } \\
\text { Cells }\end{array}$ & $\begin{array}{c}\text { Washed } \\
\text { Cells }\end{array}$ & $\begin{array}{c}\mathbf{P} \\
\text { Values }\end{array}$ & $\begin{array}{c}\text { Un- } \\
\text { washed } \\
\text { Cells }\end{array}$ & $\begin{array}{c}\text { Washed } \\
\text { Cells }\end{array}$ & $\begin{array}{c}\mathbf{P} \\
\text { Values }\end{array}$ & $\begin{array}{c}\text { Un- } \\
\text { washed } \\
\text { Cells }\end{array}$ & $\begin{array}{l}\text { Washed } \\
\text { Cells }\end{array}$ & $\begin{array}{c}\mathbf{P} \\
\text { Values }\end{array}$ \\
\hline $\begin{array}{l}\text { Unstimulated (c.p.m.) } \\
\text { PHA stimulated (c.p.m.) } \\
\text { Mitotic response* .. }\end{array}$ & .. & $\begin{array}{c}2 \cdot 084 \pm \\
0.24 \\
(121) \\
4.435 \pm \\
0.24 \\
(27260) \\
4.433 \pm \\
0.24 \\
(27100)\end{array}$ & $\begin{array}{c}2 \cdot 080 \pm \\
0 \cdot 21 \\
(120) \\
4.429 \pm \\
0 \cdot 23 \\
(26830) \\
4 \cdot 426 \pm \\
0 \cdot 23 \\
(26690)\end{array}$ & $\begin{array}{l}\text { N.S. } \\
\text { N.S. }\end{array}$ & $\begin{array}{c}2.011 \pm \\
0.32 \\
(102) \\
4.087 \pm \\
0.41 \\
(12220) \\
4 \cdot 080 \pm \\
0.42 \\
(12020)\end{array}$ & $\mid \begin{array}{c}2 \cdot 082 \pm \\
0.30 \\
(121) \\
4.428 \pm \\
0.33 \\
(26810) \\
4.426 \pm \\
0.36 \\
(26640)\end{array}$ & $\begin{array}{l}<0.001 \\
<0.001\end{array}$ & $\begin{array}{c}2.212 \pm \\
0.37 \\
(163) \\
4.345 \pm \\
0.39 \\
(22120) \\
4.33 \pm \\
0.43 \\
(21440)\end{array}$ & $\begin{array}{c}2 \cdot 116 \pm \\
0.39 \\
(131) \\
4.364 \pm \\
0 \cdot 28 \\
(23120) \\
4.36 \pm \\
0 \cdot 28 \\
(22850)\end{array}$ & $\begin{array}{l}\text { N.S. } \\
\text { N.S. }\end{array}$ & $\begin{array}{c}2.761 \pm \\
0.36 \\
(576) \\
4.638 \pm \\
0.36 \\
(43450) \\
4.620 \pm \\
0.39 \\
(41730)\end{array}$ & $\begin{array}{c}2 \cdot 752 \pm \\
0.42 \\
(565) \\
4.855 \pm \\
0.38 \\
(71530) \\
4.846 \pm \\
0.39 \\
(70200)\end{array}$ & $\begin{array}{l}\text { N.S. } \\
<0.001 \\
<0.001\end{array}$ & $\begin{array}{c}2.699 \pm \\
0.28 \\
(500) \\
4.745 \pm \\
0.24 \\
(55580) \\
4.735 \pm \\
0.25 \\
(54300)\end{array}$ & $\begin{array}{c}2 \cdot 674 \pm \\
0.35 \\
(473) \\
4 \cdot 760 \pm \\
0.27 \\
(57480) \\
4.739 \pm \\
0 \cdot 27 \\
(54840)\end{array}$ & $\begin{array}{l}\text { N.S. } \\
\text { N.S. } \\
\text { N.S. }\end{array}$ \\
\hline
\end{tabular}

* Mitotic response $=$ stimulated - unstimulated c.p.m. per culture.

N.S. = Not significant-that is, $\mathbf{P}>0.05$.

TABLE II-Lymphocyte Response to Phytohaemagglutinin: Statistical Comparison of Results Between Different Groups

\begin{tabular}{|c|c|c|c|c|c|}
\hline & & \multicolumn{2}{|c|}{ Unstimulated Counts } & \multicolumn{2}{|c|}{ Mitotic Response } \\
\hline & & Unwashed Cells & Washed Cells & Unwashed Cells & Washed Cells \\
\hline 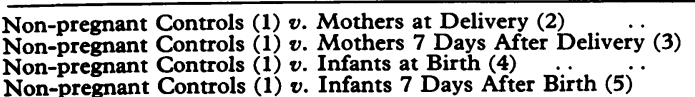 & $\begin{array}{ll}\cdots & \cdots \\
\cdots & \cdots \\
\cdots & \cdots\end{array}$ & $\begin{array}{l}\text { N.S. } \\
\text { N.S. } \\
\begin{array}{l}4>1, \\
5>1, P\end{array}<0.001 \\
\text { P }<0.001\end{array}$ & 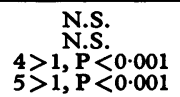 & $\begin{array}{l}2<1, \mathbf{P}<0.01 \\
\text { N.S. } \\
\text { N.S. } \\
5>1, \mathbf{P}<0.005\end{array}$ & $\begin{array}{l}\text { N.S. } \\
\text { N.S. } \\
\begin{array}{l}4>1, P \\
5>1, P<0.001\end{array}\end{array}$ \\
\hline
\end{tabular}


graft survival of skin in pregnant women (Andresen and Monroe, 1962). Our findings further indicate that this reduction in $\mathrm{T}$-cell response in pregnancy is no longer obvious seven days after delivery.

Our observation that the depressed maternal lymphocyte response to PHA returned to normal after washing the cells and removing autologous plasma from the culture provides direct evidence of an inhibitory factor in the mother's own plasma. Seven days after delivery, however, the effect of the inhibitor was not apparent. Pregnant sera may suppress the PHA response of normal adult lymphocytes (Walker et al., 1972; St Hill et al., 1973; Leikin, 1972). Various hormones, including corticosteroids (Whitfield et al., 1968), progesterone (Munroe, 1971), oestrogen (Waltman et al., 1971), and chorionic gonadotrophin (Kaye and Jones, 1971), show immunosuppressive properties. Depressed lymphocyte response to PHA in women taking oral contraceptives also suggests a nonspecific oestrogen or progesterone action (Hagan and Forland, 1972; Fitzgerald et al., 1973; Barnes, 1974). Carcinoembryonic antigen (Gold, 1967), $\alpha$-globulin (Cooperband et al., 1968), placental glycoprotein (Riggio et al., 1971), and $\alpha$-fetal protein (Purves and Geddes, 1972) have also exhibited immunosuppressive properties.

Spontaneous blast transformation of cord-blood lymphocytes in control cultures without PHA has been reported to be higher (Leikin et al., 1968; Pulvertaft and Pulvertaft, 1966), similar to (Jones, 1969), and less than (Lindahl-Kiessling and Böök, 1964) that of adult lymphocytes. Recent studies of DNA synthesis with radioactive tagging showed significantly higher background counts for unstimulated cells in cord-blood samples than for adult control cells (Montgomery et al., 1973) and our present and earlier observations (Campbell et al., 1974) also confirmed this.

Reports on the mitotic response of cord-blood lymphocytes to PHA are also conflicting. Some workers found their PHA response lower than that of adult lymphocytes (Jones, 1969; Montgomery et al., 1973; Ayoub and Kasakura, 1971), and others have shown them to parallel that of adult cells (Leikin et al., 1968; Meuwissen et al., 1968). Others showed that the response of cord-blood lymphocytes was higher than that of adult control lymphocytes (Lindalh-Kiessling and Böök, 1964; Campbell et al., 1974). Our results confirm these latter reports but only when the cells were cultured with autologous plasma removed. This inhibitory effect of newborn plasma on the infants' own cells was not obvious seven days after birth. Fetal sera suppress the PHA response of normal adult lymphocytes
(Ayonb and Kasakura, 1971) and it was postulated that separate molecules were responsible for the inhibitory effect in maternal and fetal sera (Kasakura, 1971). A recent study, however, suggested that fetal serum has a greater depressive action than maternal serum and hence the inhibitor may be derived from the fetal-placental unit (St Hill et al., 1973). The nature of the inhibitory factor is unknown and further studies are required to clarify its nature and source of this plasma inhibitory factoras well as its role in the survival of the fetal allograft in human pregnancy.

\section{References}

Andreson, R. H., and Monroe, C. W. (1962). American fournal of Obstetrics and Gynecology, 84, 1096.

Ayoub, J., and Kasakura, S. (1971). Clinical and Experimental Immunology, $8,427$.

Barnes, E. W., et al. (1974). Lancet 1, 898.

Bloom, B. R. (1971). Advances in Immunology, 13, 101.

Campbell A. C., et al. (1975). Clinical and Experimental Immunology. In Press.

Cooperbar., S. R, et al (1968), Science, 159, 1243.

Craig, A. W., Garrett, J. V., and Jackson, S. M. (1969). fournal of Clinical Pathology, 22, 558. . British Medical fournal, 3, 150. Finn, R., et al. (1972). British Medical fournal, 3, 150.
Fitzgerald, P. H., Pickering, A. F., and Ferguson, D. N. (1973). Lancet, 1, 615

Gole, P. (1967). Cancer, 20, 1663.

Hager, C., and Froland, A. (1972). Lancet, 1, 1185

Jones, W. R. (1969). American fournal of Obstetrics and Gynecology, 104, 586.

Kaye, M. D., and Jones, W. R. (1971). American fournal of Obstetrics and Gynecology, 109, 1029.

Kasakura, S. (1971). Fournal of Immunology, 107, 1296.

Leikin, S. (1972). Lancet, 2, 43.

Lekin, S., Mochir-Fatemi, F., and Park, K. (1968). Fournal of Pediatrics, $72,510$.

Lindahl-Kiessling, K., and Böök, J. A. (1964). Lancet, 2, 591.

Maini, R. N., et al. (1973). Proceedings of the 8th Leucocyte Culture Conference, Üppsala.

ference, Uppsala.
Meuwissen, $\mathrm{H}$. j., et al. (1968). Fournal of Pediatrics, 72, 177.

Meuwissen, H. J., et al. (1968). Fournal of Pediatrics, 72, 177.
Montgomery, J. R., Mason, E. O., and South, M. A. (1973). Pediatric Research, 7,365 .

Munroe J. S. (1971). Fournal of Reticuloendothelial Society, 9, 361.

Phillips, B., and Weisrose, E. (1974). Clinical and Experin ental Immunology, 16,383 .

Pulvertaft, R. J. V., and Pulvertaft, I. (1966). Lancet, 2, 892

Purtilo, D. T., Hallgren, H. M., and Yunis, E. J. (1972). Lancet, 1, 769.

Purves, L. R., and Geddes, E. W. (1972). Lancet, 1, 47.

Riggio, R. R., et ul. (1971). Transplantation, 12, 400.

Smith, J. K., Caspary, E. A., and Field, E. J. (1972). Lancet, 1, 96.

St Hill, C. A., Finn, R., and Denye, V. (1973). British Medical fournal, 3,

513.
Walker, J. S., Freeman, C. B., and Harris, R. (1972). British Medical fournal 3,169 .

Waltman, S. R., Burde, R. M., and Berrios, J. (1971). Transplantation, 11, 194.

Whitfield, J. F., Perris, A. D., and Youdale, T. (1968). Experimental Cell Research, 52, 349.

\title{
Comparison of Aerosol Ipratropium Bromide and Salbutamol in Chronic Bronchitis and Asthma
}

\author{
G. R. PETRIE, K. N. V. PALMER
}

British Medical fournal, 1975, 1, 430-432

\section{Summary}

The effects of inhaling $200 \mu \mathrm{g}$ of salbutamol were compared with those of inhaling $40 \mu \mathrm{g}$ of ipratropium bromide singly and in combination with salbutamol in

University Department of Medicine, Foresthill, Aberdeen AB9 2ZD G. R. PETRIE, M.B., M.R.C.P., Research Fellow

K. N. V. PALMER, M.B., F.R.C.P., Reader in Medicine eight patients with bronchitis and eight asthmatic patients in a double-blind controlled trial. Changes in airways resistance were assessed by measuring the forced expiratory volume in 1 second and specific airways conductance. Both drugs were significantly better in relieving airways obstruction than placebo. Salbutamol was significantly more effective than ipratropium bromide in patients with asthma, but in the patients with bronchitis there was no significant difference between salbutamol and ipratropium bromide. The combination of the two drugs produced a slightly greater and longer response than either drug alone but this was not significant. 